\section{Evolution of PTH Assays}

\begin{abstract}
PTH metabolism is complex and the circulating forms include the intact 1-84 molecule as well as several carboxyl-terminal fragments. The first generation of PTH assays included several types of competitive assays, with specificities that spanned carboxyl, mid-region and amino-terminal portions of the molecule. The limitations of these assays and the methodological evolution led to the description of $2^{\text {nd }}$ generation non-competitive immunometric assays for PTH in the late 80 's, based on the recognition of the PTH molecule by two different antibodies, one directed against de amino-terminal and other against the carboxyl-terminal segments. The observation that in some circumstances "long" carboxyl-terminal segments were also measured by $2^{\text {nd }}$ generation assays led to the development of $3^{\text {rd }}$ generation assays based on amino-terminal specific antibodies that are specific for the first amino acids, measuring only the molecular forms that activate PTHIR. The practical and cost-benefit advantages of these assays are still debatable. The recent observation that carboxyl-terminal fragments of PTH have biological activity via a distinct receptor than PTH1R, points to the future need of more than one assay in order to evaluate parathyroid hormone function. (Arq Bras Endocrinol Metab 2006;50/4:621-627)
\end{abstract}

Keywords: Parathyroid hormone assay; Radioimmunoassay; Immunometric assays; Circulating forms of parathyroid hormone

\section{RESUMO}

\section{Evolução dos Ensaios para Paratormônio.}

O metabolismo do PTH e complexo e as formas circulantes incluem o PTH 1-84, assim como fragmentos C-terminal. A primeira geração de ensaios para o PTH incluía vários ensaios competitivos com especificidades para as regiões carboxi, meio da molécula e amino-terminal. A limitação destes ensaios e a evolução metodológica, levaram ao desenvolvimento dos ensaios não competitivos de $2^{a}$. geração no final dos anos 80, baseados no reconhecimento por dois anticorpos diferentes, contra a porção amino e carboxi-terminal respectivamente. A observação que em algumas circunstâncias segmentos carboxiterminais longos também eram detectados, levou ao desenvolvimento dos ensaios de $3^{a}$. geração, baseados em anticorpos específicos para a porção aminoterminal com maior especificidade para os primeiros aminoácidos, e assim mensurando apenas a forma molecular que ativa - PTHIR. As vantagens práticas e o custo-benefício deste ensaio ainda e motivo de debate. A observação recente de que fragmentos carboxiterminais têm atividade biológica via receptor distinto, aponta para a necessidade futura de mais de um ensaio para avaliar a função do paratormônio. (Arq Bras Endocrinol Metab 2006;50/4:621-627)

Descritores: Paratormônio; Radioimunoensaio; Ensaio imunométrico; Formas circulantes do paratormônio

\section{original article}

\author{
José Gilberto H. Vieiva \\ Ilda Kunii \\ Sônia Nishida
}
Laboratório Fleury (JGHV \& SN) and Division of Endocrinology, Escola Paulista de Medicina, UNIFESP/EPM (JGHV \& IK), São Paulo, Brazil.


$\mathrm{P}$ ARATHYroid hormone (PTH) is a linear peptide of 84 amino acids, produced in the parathyroid glands, that plays a critical role as a systemic regulator of calcium, phosphate and vitamin D metabolites concentration in blood. It is also a major player in the regulation of cellular activity in bone. Classical biological activities of PTH are mediated by the PTHIR receptors present in several tissues and the amino-terminal region of the molecule contains the sequence necessary to active PTHIR. Yet PTH present in the circulation is very heterogeneous, and this heterogeneity is the consequence of a complex metabolism that initiates in the secretory granule of the parathyroid cell and continues in peripheral tissues, mainly in the liver and the kidneys $(1,2)$. The result of the complex metabolism and regulation is a very heterogeneous pool of "PTH peptides" in circulation not only in normal conditions, but mainly in primary and secondary hyperparathyroidism, specially those patients with renal insufficiency. Circulating forms that are biologically active via PTHIR have very short half-lives, and the so-called middle-region and carboxylterminal fragments, metabolized mainly via glomerular filtration, have longer half-lives (3).

Recent publications demonstrating the existence and importance of carboxyl-terminal PTH receptors have not only brought more complexity to the understanding of PTH physiology, but also to the interpretation of PTH assay results (4-6). The correct definition of what forms are recognized is of paramount importance to the correct interpretation of assay results.

The evolution of PTH measurement since the description of the first assay by Berson et al. in 1963 (7) took place in parallel to the knowledge about PTH physiology and general immunoassay assay methodology. Better methods provided more information that stimulated the development of new methods with higher sensitivity and specificity. The evolution of the knowledge in this area if far from ended, and we can foresee new and important information being unveiled in the near future.

For the sake of simplicity we divided the PTH assays in methods of the first phase of evolution, including basically competitive assays ( $1^{\text {st }}$ generation assays), and methods of the second phase, basically non-competitive assays ( $2^{\text {nd }}$ and $3^{\text {rd }}$ generation assays).

\section{FIRST PHASE: COMPETITIVE ASSAYS}

Berson et al., in 1963, described the first radioimmunoassay for human PTH (7), initiating a new era in the diagnosis of parathyroid diseases. Other radioim- munoassays followed, all of them using bovine (or porcine) PTH for labeling and antibody production. These heterologous assays were based on the crossreactivity of the antibody, generated against PTH extracted from animal glands, with human PTH. Assays with very acceptable characteristics and clinical correlation were described $(8,9)$. The problem with these assays was mainly two fold: in the first place their use was restricted due to the rarity of the antibodies, additionally their specificity was ill defined and variable, depending on preparation used for labeling and on the standard employed (10). Based on these difficulties and on the evolution of knowledge on PTH structure and peptide synthesis, two new approaches were used to develop new antibodies against human PTH: the use of human parathyroid adenoma extracts and synthetic peptides. Fischer et al. (11) were the first to describe the production of antibodies against PTH synthetic peptides, and the preparation of antisera against peptides obtained from human adenoma extracts was first described by Manning et al. (12). Synthetic sequences with a tyrosine added were used for iodine labeling, resulting in more stable, specific and reproductive assays.

The better definition of the specificity of the assays allowed their classification in three general groups: carboxyl, mid-region and amino-terminal specific, depending on the region of the molecule recognized by the antibody-tracer pair. The first to be described and the most common assays were the carboxyl-terminal specific, a practical consequence of the fact that the carboxyl-terminal portion of the molecule is more antigenic and the adenoma extracts used for immunization contained more carboxyl-terminal fragments (13). Some assays were well characterized and clinically useful, the main problem being their limited use in patients with decrease in glomerular filtration due to the retention of these fragments in this condition (14). The so called "mid-region" specific assays used PTH fragments representing the sequence between amino acids 44 to 68 as tracer, recognizing intact PTH and also some carboxyl-terminal fragments of unknown composition (15). Apparently they presented better clinical correlation than the carboxyl-terminal assays, but the limitations can be defined as similar.

Potts et al. (16), in 1971, described that the synthetic 1-34 fragment was biologically active and equipotent to the complete 1-84 sequence concerning the classical actions of PTH. Based on this knowledge, at less theoretically, the better assays should be aminoterminal specific, since they recognize the portion of the molecule known to have the classical PTH action. 
An amino-terminal specific assay was described by Desplan et al. in 1977 (17), and soon other groups also published similar assays $(18,19)$. We had a long experience with the development and use of an aminoterminal specific assay based on egg yolk-extracted antibodies produced in chicken immunized against synthetic hPTH-(1-34) (20). We also compared this assay with a carboxyl-terminal specific assay in the diagnosis of primary hyperparathyroidism (21), as well as in the evaluation of parathyroid function in patients with renal insufficiency $(14,22)$. Since the circulation of amino-terminal fragments is negligible (22), these amino-terminal specific assays measured mainly intact hormone, supposedly bioactive. Nonetheless, the amino-terminal radioimmunoassays also had some basic limitations, mainly the high sensitivity required. We should never forget that the measurement of the intact form of PTH is a methodological challenge because besides the heterogeneity of the circulating hormone, its concentration is extremely low, in the order of tents of pmol/L. The intrinsic limitations of the competitive immunoassay design restricted further development, and the rarity of good antisera and difficulties in attaining the required specific activity of the tracer, confined the amino-terminal specific assays to a few reference laboratories. In table 1 we summarize the different competitive assays developed for PTH measurement.

\section{SECOND PHASE: NON-COMPETITIVE ASSAYS}

In the late 80's, with the description of the first immunometric assays for the measurement of PTH in serum or plasma (non-competitive, "sandwich" assays, or $2^{\text {nd }}$ generation assays), almost all the difficulties of interpretation, availability and validation, common to the large variety of different competitive immunoassays ( $1^{\text {st }}$ generation), were considered overcome (23). Immunometric assays are based on two distinct anti- bodies that recognize two different epitopes, one amino-terminal and other carboxyl-terminal and, at least theoretically, measured only "intact" (1-84)PTH molecule. The meaning of "intact" PTH included the notion of bioactive PTH, or PTH that was capable of binding and activating PTHIR. Despite a remarkable improvement in diagnostic sensitivity, studies began to show that in some clinical circumstances, mainly in patients with renal insufficiency, the assays appeared to be measuring something more than just "intact" (1-84)-PTH (24). New investigations provided data suggesting that other molecular forms, specifically $\mathrm{N}$-terminally truncated $\mathrm{PTH}$-derived fragments (e.g. PTH 7-84), were also measured by the available immunometric assays $(25,26)$.

The development of a new generation $\left(3^{\text {rd }}\right)$ of immunometric assays, with the amino terminal specific antibody directed to the first four amino-terminal amino acids (fundamental for activation of the PTHIR), opened a new chapter in this field of study. It is logical to infer that an assay that claims to measure "intact" PTH should measure what it states it does. The problem is that there is controversy in the real practical superiority of these new assays.

It is now known that $2^{\text {nd }}$ generation PTH assays measure more than PTH-(1-84) (figure 1), but how much more can vary between different assays. Despite a general agreement and uniformity of the normal range expected for these assays, slight differences were observed in their cross-reactivity with the 7-84 peptide, probably related to differences in the specificity of the amino terminal specific antibodies used (27). Some assays use polyclonal affinity-purified antibodies (obtained in goat, sheep or chicken), other use monoclonal antibodies $(23,28)$. But is the 7-84 sequence the only "long carboxyl-terminal" fragment present? Almost certainly not, and the cross-reactivity of the different assays with the various fragments can account for the slight differences in the "intact" PTH values obtained with the available commercial assays. Third

Table 1. General classification of competitive PTH assays.

1 Assays using antibodies generated against bovine (or porcine) PTH extracted from glands and the same preparation labeled with lodine as tracer.

2 Assays using antibodies generated against human PTH adenoma extracts and bovine or human labeled PTH preparations as tracer.

3 Assays using antibodies generated against human or bovine PTH preparations and synthetic carboxyl, mid-region or amino-terminal sequences.

4 Assays using antibodies generated against synthetic human PTH peptides (carboxyl, mid-region and amino-terminal) and the corresponding thyrosilated synthetic peptide labeled with lodine as tracer. 


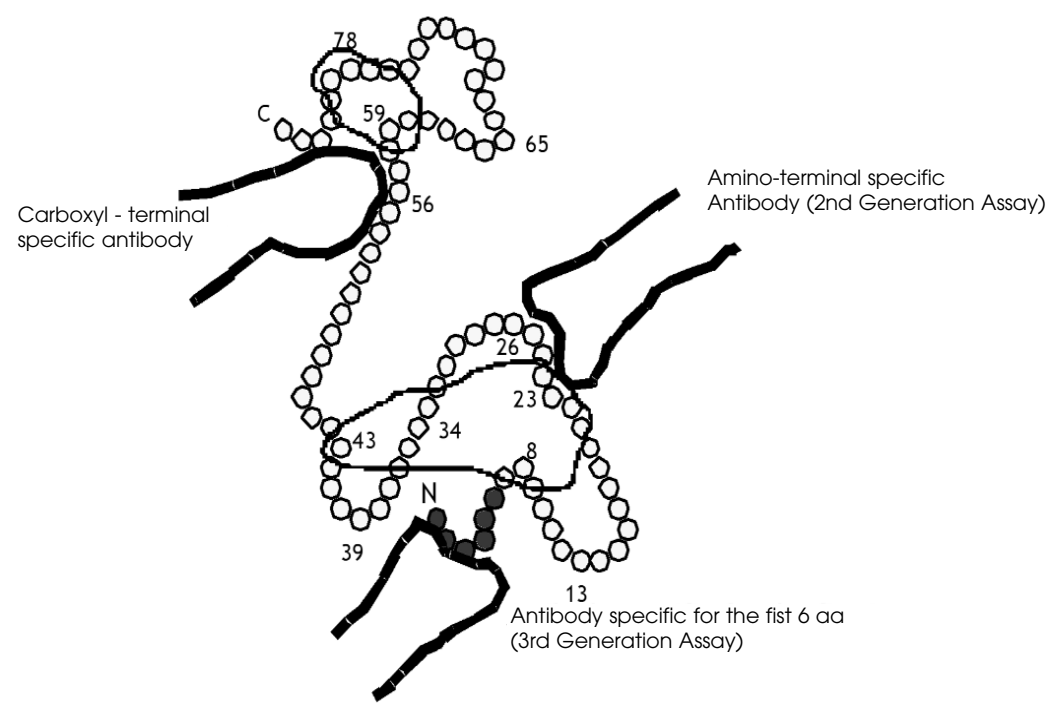

Figure 1. Schematic representation of 2 nd and 3 rd generation immunometric assays for PTH. The carboxyl-terminal antibody is common to both assays; amino-terminal specific antibody of 2nd and 3rd generation recognizes different portions of the molecule.

generation assays do not suffer from this incertitude, at least in what concerns the amino-terminal antibody specificity. Only PTH forms including the first 1-4 amino acids are recognized (figure 1). The epitopes recognized by the other antibody, the carboxyl-terminal specific, can also potentially lead to slight differences between methods.

\section{$2^{\text {nd }} \times 3^{\text {rd }}$ Generation Assays in the Diagnosis of Primary Hyperparathyroidism (PHP)}

In typical patients with PHP it is difficult to image how a more specific, $3^{\text {rd }}$ generation assay for PTH would improve the diagnostic accuracy, since most of the patients have normal renal function. Maybe in borderline cases, where the clinical and laboratory data are dubious, a more specific assay would help. Clear evidence that the $3^{\text {rd }}$ generation assay improves diagnostic sensitivity and specificity is still disputable (29-31). One point not to be neglected is the huge clinical experience accumulated with the $2^{\text {nd }}$ generation assays during more than 15 years of extensive use. A real conclusion about the superiority of the $3^{\text {rd }}$ generation assays must include a solid definition of the normal range and extensive clinical experience. Concerning the intra-operative PTH measurement, $3^{\text {rd }}$ generation assays also have the potential of being more useful, since the half-life of (1-84)-PTH is shorter than the half-life of the potential nt-(1-84)-PTH fragments present. That would allow an earlier identification of a significant fall in PTH levels, but this diagnostic improvement also remains to be documented. One last point that must be analyzed is the cost-benefit of the information obtained by the two assays, since the $3^{\text {rd }}$ generation assays tend to be more expensive and not widely available.

\section{$2^{\text {nd }} \times 3^{\text {rd }}$ Generation Assays in the Diagnosis of Hyperparathyroidism Secondary to Renal Insufficiency (SHP)}

Since the introduction of $2^{\text {nd }}$ generation PTH assays, the levels of PTH in patients with renal insufficiency were found to be higher than the clinical, and most importantly, the bone histomorphometric presentation, would predict. The seminal work of Quarles et al. in 1992 (24) was the first to clearly demonstrate this fact and since then, values two to three times the upper limit of normality where considered as reflecting a normal PTH function in patients with renal insufficiency. The first, and simplest answer to this observation was that there was a resistance to PTH action in these patients, which proved to be at least partially true. Meanwhile Brossard and colleagues, in 1996 (32), were the first to show that there was an accumulation of other non-(1-84) forms in ESRD patients that were measured by "intact" PTH assays $\left(2^{\text {nd }}\right.$ generation) as well as the true biologically active (1-84)PTH. In figure 2 we depict our experience, using our $2^{\text {nd }}$ generation assay $(28)$ in samples from patients with PHP and samples from patients with SHP, submitted to HPLC fractionation. The second peak corresponds 
to (1-84)-PTH forms, and the first to lower molecular weight forms, supposedly (7-84)-PTH. The peak exists in both groups of patients, but is significantly more important in the patients with renal insufficiency. Besides the quite unpredictable factor of how much of the PTH measured by a $2^{\text {nd }}$ generation assay corresponds to PTH that binds and activates PTHIR, there is the variable of the transient effects of the therapy imposed to ESRD patients. The use of phosphate binders, calcium and vitamin $\mathrm{D}$ supplementation, dialysis bath calcium concentration, aluminum intoxication, all induce PTH function short- and long-term modifications that can have an immediate effect in the PTH serum levels but would only affect bone biopsy findings if they persist for a long time.

The introduction of $3^{\text {rd }}$ generation assays that, by definition, measure only (1-84)-PTH, brought the possibility that in patients with secondary hyperparathyroidism due to renal insufficiency we would obtain results with a more real meaning. In these patients, the retention of long carboxyl-terminal fragments potentially interferes with the results of $2^{\text {nd }}$ generation assays. A simplistic approach would be to consider that since these fragments don't interfere in $3^{\text {rd }}$ generation assays, the results obtained with this latter type of assay could be interpreted as a real portrait of the PTH function status. Some recent publications showed that this could be the case, in special if you measure PTH using both $2^{\text {nd }}$ and $3^{\text {rd }}$ generation assays and use the difference between results, the so-called nt-(1-84)-PTH, to calculate a relationship between the PTHIR active ((1-84)-PTH) and non-active (nt(1-84)-PTH), or “7-84" forms $(33,34)$.

In spite of all logic behind this approach, other

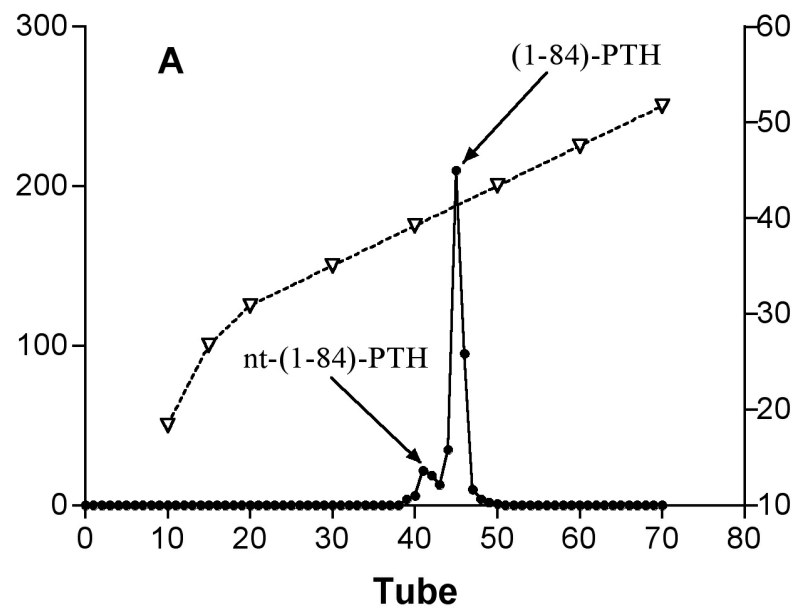

publications, from several reference centers showed that the correlation between bone status and PTH measurements in patients with ESRD was similar using $3^{\text {rd }}$ or $2^{\text {nd }}$ generation assays $(35,36)$. The same observation stands for the relationship between the "I84/7-84" relationship. Furthermore, the correlation between PTH values obtained with $2^{\text {nd }}$ and $3^{\text {rd }}$ generation assays is excellent, even in patients with ESRD. To try to understand why the logic does not seem to work two aspects must be taken into account: first that the nt-(1-84)-PTH that we are measuring (by subtracting $2^{\text {nd }}$ generation from $3^{\text {rd }}$ generation assay values) does not include a significant part of the C-terminal receptor binding peptides, not recognized by the $2^{\text {nd }}$ generation assays. The second aspect is that different factors, not directly related to PTH levels, contribute, in variable degree, to the PTH resistance status seen in patients with ESRD.

One important point concerning the physiological role of the nt-(1-84)-PTH forms are the recent publications by Divieti et al. $(4,5)$ showing that this forms have biological action that is independent of activation or blocking of PTHIR. More importantly, a putative CPTH receptor can be activated by forms shorter than (7-84)-PTH. These include (24-84)-PTH and even, albeit with less affinity, (39-84)-PTH. These findings can have important implications on the interpretation of the $2^{\text {nd }} / 3^{\text {rd }}$ generation PTH measurement ratios in ESRD patients, since the $2^{\text {nd }}$ generation assays are usually based on antibodies that recognize epitopes in the amino terminal region that may not be present in some of the "shorter" nt-(1-84)-PTH fragments. In other words, in this specific context, an immunometric assay using an antibody recognizing a different epitope

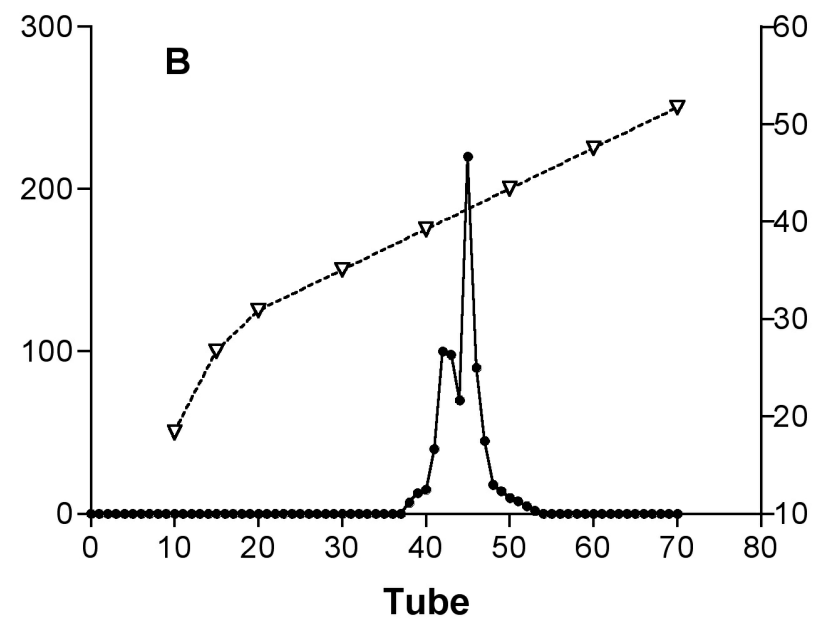

Figure 2. Elution profiles obtained by HPLC for serum from a patient with primary hyperparathyroidism ( $A$ ) and hyperparathyroidism secondary to chronic renal failure (B). nt-(1-84)-PTH= n-truncated (1-84)-PTH fragments. 
(including amino acids 30 to 40 for example) could potentially provide more information than the traditional $2^{\text {nd }}$ generation assays. The notion that ionized calcium concentration contributes to the modulation of circulating PTH immunoheterogeneity adds additional complexity to the interpretation of PTH measurement in ESRD patients (2). Metabolism of carboxyl-terminal fragments in these patients is highly compromised by the declining glomerular filtration rates.

\section{CONCLUSIONS}

The evolution of PTH assays has been remarkable, but as usually happens, also our knowledge on the complex metabolism of this hormone evolved in parallel. The notion that PTH is a "polyhormone" was raised for the first time by Mallette (37) and is acquiring even more plausibility by the recent description of several different forms of circulating PTH (38-40). These observations, together with the evidence of the presence of a carboxyl-terminal specific receptor (4-6), point to a more complex scenery where different clinical conditions will require different assays in order to define the complex situation of parathyroid physiology. For the definition of primary hyperparathyroidism, where we are concerned with the PTH forms that act on the PTHIR (classical pathway), the available $2^{\text {nd }}$ generation assays are quite satisfactory $(41)$, and the $3^{\text {rd }}$ generation assays may have advantages only in special conditions. In the presence of renal insufficiency $2^{\text {nd }}$ generation assays are informative for most situations, being the use of $3^{\text {rd }}$ generation assays dependent on their availability and validation of their cost-benefit.

Parathyroid function is complex and subject to several different influences. Maintenance of serum calcium in a very strict normal level is only one of the physiological functions of this hormone. We think that for the evaluation of the complex PTH influence in bone and mineral metabolism, different assays recognizing "long" carboxyl-terminal forms will be required in some situations, complementing the information obtained by $2^{\text {nd }} / 3^{\text {rd }}$ generations assays.

\section{REFERENCES}

1. Silverman R, Yalow RS. Heterogeneity of parathyroid hormone: clinical and physiologic implications. J Clin Invest 1973:52:1958-71

2. D'Amour P, Palardy J, Bahsali $G$, Mallette LE, DeLéan A, Lepage R. The modulation of circulating parathyroid hormone immunoheterogeneity in man by ionized calcium concentration. J Clin Endocrinol Metab 1992;74:525-32.
3. Martin KJ, Hruska KA, Lewis J, Anderson C, Slatopolsky E. The renal handling of parathyroid hormone: role of peritubular uptake and glomerular filtration. J Clin Invest 1977;60:808-14.

4. Divieti $P$, Inomata $N$, Chapin $K$, Singh $R$, Jüppner $H$, Bringhurst FR. Receptors for carboxyl-terminal region of PTH(1-84) are highly expressed in osteocytic cells. Endocrinology 2001;142:916-25.

5. Divieti $P$, John MR, Jüppner $H$, Bringhurst FR. Human PTH(7-84) inhibits bone resorption in vitro via actions independent of the type 1 PTH/PTHrP receptor. Endocrinology 2002; 143:171-6.

6. Divieti P, Geller Al, Suliman G, Jüppner H, Bringhurst FR. Receptors specific for the carboxyl-terminal region of parathyroid hormone on bone-derived cells: determinants of ligand binding and bioactivity. Endocrinology 2005; 146:1863-70.

7. Berson SA, Yalow RS, AurbachGD, Potts Jr JT. Immunoassay of bovine and human parathyroid hormone. Proc Natl Acad Sci USA 1963:49:613-6.

8. Reiss E, Canterbury JM. A radioimmunoassay for parathyroid hormone in man. Proc Soc Exp Biol Med 1968; $128: 501-4$

9. Arnaud CD, Tsao HS, Littledike T. Radioimmunoassay of human parathyroid hormone in serum. J Clin Invest 1971;50:21-34.

10. Mallette L. Sensitivity of bovine parathyroid hormone serum $211 / 32$ to synthetic fragments of human parathyroid hormone. J Clin Endocrinol Metab 1980;50:201-3.

11. Fischer JA, Binswanger U, Dietrich FM. Human parathyroid hormone. Immunological characterization of antibodies against a glandular extract and the synthetic fragments 1-12 and 1-34 and their use in the determination of immunoreactive hormone in human sera. J Clin Invest 1974;54:1382-94.

12. Manning RM, Hendy GN, Papapoulos SE, O'Riordan JLH. Development of homologous immunological assays for human parathyroid hormone. J Endocr 1980;85:161-70.

13. Simon $M$, Cuan J. C-terminal parathyrin (parathyroid hormone) radioimmunoassay in serum with commercially available reagents. Clin Chem 1980;26:1672-6.

14. Zanella MT, Silva MC, Pers RB, Ferreira SRG, Draibe SA, Vieira JGH. Radioimmunoassay of carboxyl and amino terminal fragments of parathyroid hormone for the evaluation of secondary hyperparathyroidism in chronic renal failure. Braz J Med Biol Res 1990;23:235-43.

15. Marx SJ, Sharp ME, Krudy A, Rosenblatt M, Mallette LE. Radioimmunoassay for the middle region of human parathyroid hormone: studies with radioiodinated synthetic peptides. J Clin Endocrinol Metab 1981;53:76-84.

16. Potts JT Jr, Tregear GW, Keutmann HT, Niall HD, Sauer R, Deftos LJ, et al. Synthesis of a biologically active N-terminal tetratriacontapeptide of parathyroid hormone. Proc Natl Acad Sci USA 1971:68:63-7.

17. Desplan C, Julienne A, Moukhtar MS, Milhaud G. Sensitive assay for biological active fragment of human parathyroid hormone. Lancet 1977;ii:198-9.

18. Visser TJ, Buurman CJ, Birkenhäger JC. Immunological studies of parathyroid hormone: characterization of antisera to the synthetic 1-34 human parathyroid hormone and evidence that position 30 is aspartic acid. J Endocr 1977;74:461-6. 
19. Atkinson MJ, Jüpnner $\mathrm{H}$, Niepel B, Casaretto $\mathrm{M}$, Zahn $\mathrm{H}$, Hesch RD. Characterization of binding sites of antiparathyroid hormone antisera using synthetic parathyroid hormone peptides. J Immunoassay 1982;3:31-51.

20. Vieira JGH, Oliveira MAD, Maciel RMB, Mesquita $\mathrm{CH}$, Russo EMK. Development of an homologous radioimmunoassay for the synthetic amino terminal (1-34) fragment $f$ human parathyroid hormone using egg yolkobtained antibodies. J Immunoassay 1986;7:57-72.

21. Vieira JGH, Oliveira MAD, Hidal JT, Russo EMK, Chacra AR. Critical analysis of two segment-specific radioimmunoassays for the measurement of parathyroid hormone and their use in the diagnosis of primary hyperparathyroidism. Rev Ass Med Brasil 1988:34:79-83 (article in Portuguese).

22. Brandão CM, Kasamatsu TS, Oliveira MA, Vieira JG. Circulating molecular forms of parathyroid hormone in primary and secondary hyperparathyroidism. Braz J Med Biol Res 1989:22:963-5

23. Nussbaum SR, Zahradnik RJ, Lavigne JR, Brennan GL, Nozawa-Ung K, Kim L, et al. Highly sensitive two-site immunoradiometric assay of parathyrin and its clinical utility in evaluating patients with hypercalcemia. Clin Chem 1987;33:1364-7.

24. Quarles LD, Lobaugh B, Murphy G. Intact parathyroid hormone over-estimates the presence and severity of parathyroid mediated osseous abnormalities in uremia. J Clin Endocrinol Metab 1992;75:143-50.

25. John MR, Goodman WG, Gao P, Cantor TL, Salusky IB, Jüppner $\mathrm{H}$. A novel immunoradiometric assay detects full-length human PTH but not amino-terminally truncated fragments: implications for PTH measurements in renal failure. J Clin Endocrinol Metab 1999:84:4287-90.

26. Kunii IS, Vieira JGH. Circulating forms of parathyroid hormone detected with an immunofluorometric assay in patients with primary hyperparathyroidism and in hyperparathyroidism secondary to chronic renal failure. Braz J Med Biol Res 2001;34:1547-50.

27. Vieira JG, Nishida SK, Camargo MT, Obara LH, Kunii IS, Ohe MN, et al. PTH values obtained using immunometric assays depend on the specificity of the amino-terminal specific antibody used. Arq Bras Endocrinol Metab 2004:48:518-24 (article in Portuguese).

28. Vieira JGH, Nishida SK, Kasamatsu TS, Amarante EC, Kunii IS. Development and application of an immunofluorometric assay for intact parathyroid hormone. Braz J Med Biol Res 1994:27:2379-82

29. Silverberg S, Gao P, Braown I, LoGerfo P, Cantor T, Bilezikian J. Clinical utility of an immunoradiometric assay for parathyroid hormone (1-84) in primary hyperparathyroidism. J Clin Endocrinol Metab 2003;88:4725-30.

30. Carnevale V, Dionisi S, Nofroni I, Romagnoli E, Paglia F, De Geronimo S, et al. Potential utility of a new IRMA for parathyroid hormone in post menopausal patients with primary hyperparathyroidism. Clin Chem 2004;50:626-31.

31. Boudou P, Ibrahim F, Cormier C, Chabas A, Sarfati E, Souberbielle J-C. Third or second generation parathyroid hormone assays: a remaining debate in the diagnosis of primary hyperparathyroidism. J Clin Endocrinol Metab 2005;90:6370-2.
32. Brossard J-H, Cloutier M, Roy L, Lepage R, Gascon-Barré $\mathrm{M}, \mathrm{D}$ 'Amour P. Accumulation of a non-(1-84) molecular form of parathyroid hormone (PTH) detected by intact PTH assay in renal failure: importance in the interpretation of PTH values. J Clin Endocrinol Metab 1996;81:3923-9.

33. Lepage $R$, Roy L, Brossard J-H, Rousseau L, Dorais C, Lazure $C$, et al. A non-(1-84) circulating parathyroid hormone (PTH) fragment interferes significantly with intact PTH commercial assay measurements in uremic samples. Clin Chem 1998;44:805-9.

34. Monier-Faugere M-C, Geng Z, Mawad H, Friedler RM, Gao P, Cantor TL, et al. Improved assessment of bone turnover by the PTH-(1-84)/large C-PTH fragments ratio in ESRD patients. Kidney Int 2001;60:1460-8.

35. Coen $G$, Bonucci $E$, Ballanti $P$, Balducci A, Calabria S, Nicolai GA, et al. PTH 1-84 and PTH "7-84" in the noninvasive diagnosis of renal bone disease. Am J Kidney Dis 2002;40:348-54.

36. SaluskyIB, Goodman WG, Kuizon BD, Lavigne JR, Zahranik RJ, Gales B, et al. Similar predictive value of bone turnover using first- and second generation immunometric PTH assays in pediatric patients treated with peritoneal dialysis. Kidney Int 2003;63:1801-8.

37. Mallette LE. The parathyroid polyhormones: new concepts in the spectrum of peptide hormone action. Endocr Rev 1991;12:110-7.

38. D'Amour P, Brossard JH, Rousseau L, Nguyen-Yamamoto L, Nassif E, Lazure C, et al. Structure of non-(1-84) PTH fragments secreted by parathyroid glands in primary and secondary hyperparathyroidism. Kidney Int 2005;68:998-1007.

39. Räkel A, Brossard J-H, Patenaude J-V, Albert C, Nassif E, Cantor $\mathrm{T}$, et al. Overproduction of an amino-terminal form of PTH distinct from human PTH(1-84) in a case of severe primary hyperparathyroidism: influence of medical treatment and surgery. Clin Endocrinol 2005;62:721-7.

40. D'Amour P, Brossard J-H, Räkel A, Rousseau L, Albert C, Cantor T. Evidence that the amino-terminal composition of non-(1-84) parathyroid hormone fragments starts before position 19. Clin Chem 2005;51:169-76.

41. Blumsohn A, Hadari AA. Parathyroid hormone: what are we measuring and does it matter? Ann Clin Biochem 2002;39:169-72.

\section{Address for correspondence:}

José Gilberto H. Vieira

Laboratório Fleury

Av. General Waldomiro de Lima 508

04344-070 São Paulo, SP, Brasil

E-mail: jose.vieira@fleury.com.br 